\title{
DISCUSSÕES SOBRE O PAPEL DOS ESPAÇOS LIVRES PÚBLICOS NOS BAIRROS DE ELITE CONTEMPORÂNEOS
}

Fábio Mariz Gonçalves

Arquiteto e doutor pela FAUUSP, professor de paisagismo da FAUUSP

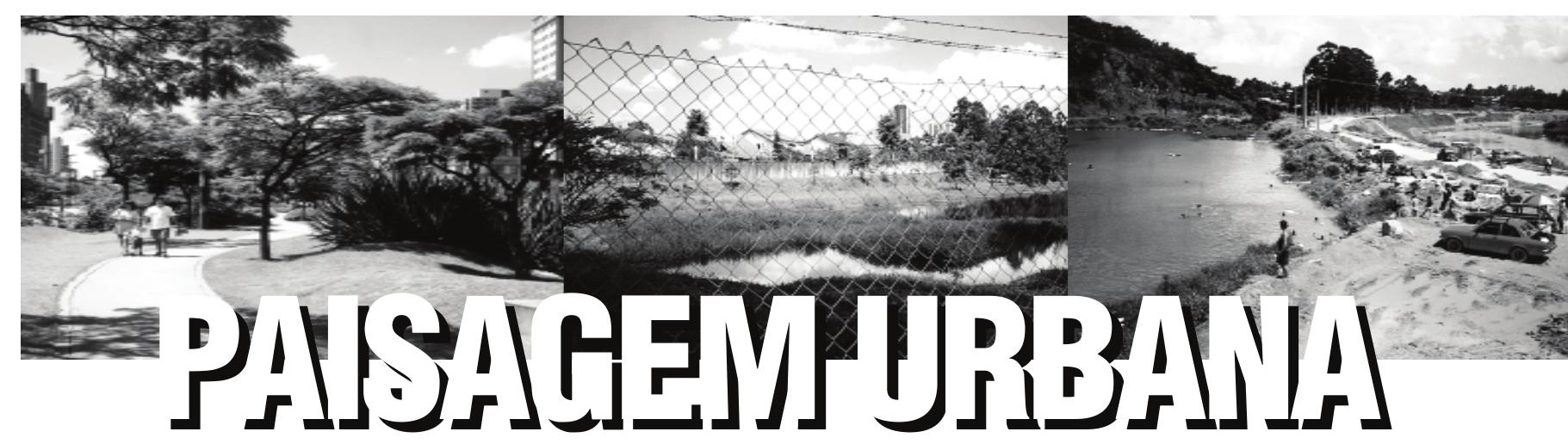




\section{RESUMO}

Tendo como objeto de estudo três bairros de elite contemporâneos (o Morumbi e o Alphaville, em São Paulo, e a Barra da Tijuca, no Rio de Janeiro). Debate-se que a superação dos conflitos decorrentes da inadequação dos padrões urbanísticos institucionais ao suporte físico original depende da implantação de um sistema de espaços livres urbanos públicos. Defende-se que a implantação e a sobrevivência deste sistema de espaços livres depende da superação de padrões sociais, culturais e econômicos que vêm minando a possibilidade de convivência de classes sociais distintas.

Aponta-se que o abandono e o desequilíbrio que a paisagem urbana brasileira - especialmente a paulistana - vem apresentando são conseqüências da omissão do Estado na condução do acordo social necessário para a superação do atual estágio de segregação recíproca das diferentes classes sociais.

\section{ABSTRACT}

This paper addresses the need of a public open space system in order to overcome official urban development patterns inadequate to the original physical support by studying three contemporary elite neighborhoods. It asserts that the public space survival depends on the change of social, cultural and economic aspects that undermines the possibility of diverse social classes coexistence.

It concludes that the neglected brazilian urban landscape, and specially the one of São Paulo, is a result of the state omission in leading a social pact needed to finish the present stage of spatial segregation of different social classes. 


\section{DISCUSSÕES SOBRE O PAPEL DOS ESPAÇOS LIVRES PÚBLICOS NOS BAIRROS DE ELITE' CONTEMPORÂNEOS}

No início de 1999 defendemos o doutorado ${ }^{2}$ que vinha sendo desenvolvido desde 1989 e que, ao longo dos dez anos de pesquisa, sofreu inúmeras alterações, mantendo-se fiel apenas ao objeto original de estudo, a região do Morumbi em São Paulo. Nos últimos anos o trabalho acabou ganhando estudos complementares sobre a região de Alphaville, em Barueri, e a Barra da Tijuca, no Rio de Janeiro, constituindo-se em uma reflexão acerca da paisagem dos bairros de elite contemporâneos das duas maiores metrópoles brasileiras.

Durante o desenvolvimento dos trabalhos algumas questões, inicialmente secundárias, ganharam importância, outras perderam.

Estamos convencidos de que ter estudado os bairros da elite contemporânea deu-nos um novo entendimento acerca do trabalho do arquiteto paisagista, do urbanista e principalmente do professor das nossas faculdades de arquitetura brasileiras. Lecionar exige uma reflexão permanente sobre o papel do profissional em nossa sociedade.

Qual o papel que os arquitetos têm desempenhado na nossa sociedade presente? Qual a cidade que estamos construindo diariamente? Quais os edifícios, parques e espaços que a nossa sociedade tem produzido?

Arquitetura é um produto social, arquiteto algum é capaz de conceber espaços e construí-los sozinho. Quem apresenta as demandas é a sociedade, quem constrói a cidade é a sociedade, a paisagem espelha a ordem e a desordem da sociedade que a constrói.

(1) As elites a que nos referimos são as elites econômicas.

(2) GONÇALVES, Fábio Mariz. O desenho da paisagem - A relação entre os padrões de urbanização e o suporte físico. São Paulo, 1999. Tese (Doutorado), FAUUSP. 
Contudo, a participação de cada agente produtor da paisagem é distinta em natureza e importância. Pode-se apontar a contribuição de cada um, desde os cidadãos comuns, moradores e trabalhadores em geral até a parcela da sociedade mais comprometida diretamente com a produção do espaço urbano - incorporadores, investidores, construtores, corretores, arquitetos, etc.

Ao arquiteto, enquanto profissional inserido neste processo, cumpre desenhar os espaços e as obras, acatando os prazos, as técnicas, as formas e as determinações - questionando, contudo, o seu fazer, criticando o produto de seu trabalho, procurando experimentar, avançar ou mesmo subverter as práticas comuns da nossa sociedade, dentro das limitadas possibilidades existentes.

Para o exercício profissional crítico é fundamental o entendimento dos processos sociais, culturais e econômicos da sociedade em que exercemos nosso ofício. A qualidade do projeto será maior quanto melhor for o entendimento que o profissional tem das reais questões que interferem em sua prática profissional.

A mencionada qualidade do projeto não é a comercial, não deve ser pensada para ser apreciada nos balcões de vendas, mas para gerar usos e apropriações interessantes para a própria população. Reside fundamentalmente na concepção urbana subjacente ao projeto, nos méritos urbanísticos que qualquer projeto apresenta, seja de uma simples residência até um centro empresarial. Esta qualidade, acreditamos, não surge de idéias abstratas ou teóricas acerca do funcionamento da sociedade, mas da observação cuidadosa e crítica do cotidiano, da prática, do discurso e da realidade urbana brasileira contemporânea, depende do domínio e do entendimento correto da realidade a ser enfrentada.

Todo o estudo que desenvolvemos durante o doutorado versava sobre os bairros de elite contemporâneos. As três regiões estudadas (do Morumbi e de Alphaville, em São Paulo, e da Barra da Tijuca, no Rio de Janeiro) foram percorridas, observando como estas áreas estão sendo construídas, como estão sendo vendidas pela mídia imobiliária, como estão sendo vistas pela imprensa não-especializada, como estão sendo cuidadas pelo poder público e pelos seus moradores.

Após os vários estudos encerramos o trabalho abordando alguns temas que nos preocupavam naquele momento: "A morte do espaço livre público ou a segregação dos diferentes"; "Questões ambientais e paisagísticas"; "Questões sociais"; e "O papel do Estado e do planejamento". 
Aproveitamos este espaço para esclarecer seus conteúdos para os colegas e alunos que se interessem por discutir os desafios que os arquitetos enfrentam ao trabalhar em contextos dos bairros elitizados contemporâneos.

\section{A Morte do Espaço Livre Público ou a Segregação dos Diferentes}

Ao percorrer as áreas livres públicas (ruas e praças) de alguns setores do Morumbi, observamos como estas se apresentam malcuidadas, abandonadas pelos moradores, empreendedores e pela municipalidade. Esta falta de cuidado com os espaços pareceu-nos ser explicável pela impossibilidade de a elite segregar-se da miséria que a rodeia, pela "impossibilidade de convivência" entre as diferentes classes sociais.

Bairros operários e pobres, com seus lotes pequenos e casas simples, são comuns na zona leste e nas periferias de toda a cidade, como São Miguel, Vila Maria ou Vila Sônia. No sistema capitalista de produção da cidade, quem pode pagar pela terra, pela boa localização, pelo "ponto", fica mais próximo do centro e dos bairros mais bem servidos de infra-estrutura e empregos, como explica Flávio Villaça ${ }^{3}$.

Contudo, quem não tem sequer as mínimas condições de participar do processo capitalista de segregação social acaba desrespeitando suas regras: os pobres e miseráveis que sobrevivem da economia paralela ou de subempregos procuram morar em favelas próximas aos seus "trabalhos".

Se, no final dos anos 90, o Morumbi ainda apresentava grandes vazios, o que dizer do bairro nos anos 70, quando apresentava extensas áreas inacessíveis, ruas de terra e terrenos "sem donos"? Nos anos 70, 1, 1\% da população de São Paulo morava em favelas; em 1987, essa porcentagem ainda era inferior a 9\%; em 1993, segundo levantamento da Fipe, 19,4\% da população paulistana morava em favelas. $O$ bairro da elite também é o bairro das favelas mais "bem localizadas" da cidade.

As estatísticas da região do Morumbi demonstram a dualidade de seus moradores. Segundo os resultados do Censo de 1991, os

(3) VILLAÇA, José Magalhães. Sistematização crítica da obra escrita sobre espaço urbano. São Paulo: FAUUSP, concurso para professor livre-docente, 1989. 
distritos do Morumbi e Vila Andrade, que praticamente coincidem com os limites da área estudada, apresentam contradições notáveis.

A renda do chefe do domicílio, dos dois distritos, é de mais de 10 salários mínimos, a mesma faixa do Jardim Paulista, Itaim ou Alto de Pinheiros; contudo, o analfabetismo no distrito do Morumbi fica na faixa de 10 a 15\%; na Vila Andrade, essa taxa é de mais de 15\%, ao passo que no Jardim Paulista e Alto de Pinheiros fica na faixa de 0 a $6 \%$.

Segundo o Programa de Aprimoramento das Informações de Mortalidade no Município de São Paulo - Proaim, vinculado ao Serviço Funerário Municipal, a taxa de homicídios nos dois distritos é de mais de 45 mortes/100.000 hab., enquanto no Jardim Paulista e Alto de Pinheiros a taxa fica na faixa de 0 a 20 mortes/100.000 habitantes. Esses dados são de 1991, mas a violência na área já foi apontada como a principal responsável por uma grande desvalorização dos imóveis desde os anos $60^{4}$.

A região do Morumbi conta com várias favelas nos seus fundos de vale e nas encostas íngremes, "empregando" a maioria dos seus moradores em trabalhos domésticos e como pedintes em semáforos. Esses "vizinhos indesejados" utilizam todos os espaços livres, públicos ou privados, disponíveis para sua recreação: ruas, terrenos baldios, murados ou não, são aproveitados para o lazer dos moradores de todas as idades. É lógico que eles acabam por utilizar as mesmas ruas, praças e parques dos "moradores legítimos", os donos das terras.

É comum explicar a pouca manutenção e o pouco uso dos espaços livres do bairro pelos equipamentos existentes dentro dos lotes e pelo fato de que a burguesia se desloca em automóveis, não utilizando suas ruas e praças. São afirmações verdadeiras, mas insuficientes, pois, se bastassem, nos jardins (América e Europa) e nos condomínios fechados os espaços livres também seriam malcuidados, o que não ocorre.

Maria Angela F. Pereira Leite faz uma síntese da crise dos espaços livres públicos em situações de grave disparidade social, quando

(4) Dados obtidos em MARICATO, Ermínia. Metrópole na periferia do capitalismo: Legalidade, desigualdade e violência. São Paulo: Hucitec, 1996. 
afirma: "A renúncia ao espaço público da cidade fica caracterizada por uma série de procedimentos diferentes: nas camadas de mais alta renda, pelo desenvolvimento privado das atividades culturais e de lazer; nas de baixo poder aquisitivo, pela impossibilidade de participar de atividades públicas sociais ou culturais, seja pelo temor de sair de casa após o anoitecer - pois não há garantia de segurança - seja pela sua marginalização no processo de desenvolvimento cultural; a atuação do poder público agrava essa situação pelo isolamento - por meio de grades, muros ou procedimentos intimidatórios - dos espaços públicos de uso coletivo, visando atender a alegações de caráter essencialmente discriminatório: falta de segurança gerada pela permanência, nas praças, parques e jardins, de 'desocupados' ou 'suspeitos', ou falta de condições intelectuais para a participação popular em atividades culturais." ${ }^{5}$

Outra constatação que confirma esse fato é que quanto mais se desloca, na região do Morumbi, das áreas menos consolidadas, ao sul, para as áreas mais consolidadas, ao norte, portanto mais segregadas, a manutenção desses espaços melhora, embora sua utilização continue pequena.

A presença dessa população miserável na área é tão indesejada pelos moradores e prejudicial aos investidores que, no plano da gestão Mário Covas ${ }^{6}$, era proposta uma operação urbana específica para a regularização fundiária da Favela do Paraisópolis, a maior da região. Ressalta-se que de todo o município esta foi a única favela a merecer tal "atenção". Nessa proposta havia a preocupação de se "manter os moradores na região", o que seria extremamente ou "convenientemente" difícil, em face da pressão imobiliária sobre a área.

Leis e práticas mercadológicas cuidavam de reservar áreas verdes e ajardinadas nos bairros de elite antes mesmo da Lei Municipal n. 9.413, que regulamentou o parcelamento do solo no município,

(5) LEITE, Maria Angela F. Pereira. A natureza e a cidade: Rediscutindo suas relações. In: Natureza e sociedade de hoje: Uma leitura geográfica. São Paulo: Hucitec, 1993.

(6) O Plano Diretor do Município de São Paulo, desenvolvido em 1985, na gestão do prefeito Mário Covas. Esse plano não foi aprovado, mas grande parte dele foi aproveitada no plano aprovado no último mês da gestão do prefeito Jânio Quadros, materializando-se na Lei n. 10.676 de 7 de novembro de 1988. 
praticamente ratificando as determinações da Lei Federal n. 6.766, de 1979, a Lei Lehman".

\section{Essas áreas não são encontradas em toda a região ao sul do Palácio} dos Bandeirantes e, quando existem, são meros gramados malcuidados, sem equipamentos, mobiliário, arborização ou qualquer elemento de interesse. Nos bairros de elite mais antigos, mesmo anteriores a essa lei, esses espaços existem em abundância. Na área estudada, eles só comparecem implantados e mantidos quando a região aparece consolidada, ou seja, quando é de uso restrito à elite ${ }^{8}$.

A questão do significado dos espaços livres urbanos está diretamente ligada à discussão dos modelos urbanos a adotar. Em um sítio complexo e frágil como o Morumbi, é natural que existam várias áreas que deverão permanecer necessariamente livres de edificações, como era proposto no plano da gestão do governo Mário Covas. É certo que nem todas essas áreas terão de ser públicas, mas para que permaneçam livres deverão assumir algum papel ou significado urbano relevante. A discussão do significado e papel dos espaços livres urbanos é fundamental para que se possa definir seu desenho, distribuição e quantidade.

A manutenção a que se refere é manifestada no cuidado com a limpeza e com o tratamento dos muros, calçadas e jardins, realizado tanto pelos proprietários como pela municipalidade. Aparentemente a segregação social tem sido uma condição para que a elite ou o Estado se comprometam efetivamente com a manutenção do

(7) A Lei Municipal n. 9.413 de 30 de dezembro de 1981, dispõe sobre o parcelamento do solo no Município de São Paulo. Reproduz diversos itens da lei federal, estabelecendo como diretrizes específicas: "da área total, objeto do projeto de loteamento, serão destinados, no mínimo: a) 20\% para vias de circulação de veículos; b) 15\% para áreas verdes; c) 5\% para áreas institucionais". "a localização das áreas verdes deverá atender às seguintes disposições: a) 50\% do percentual exigido para as áreas verdes será localizado pela prefeitura em um só perímetro e em parcelas de terreno que por sua configuração topográfica, não apresentem declividade superior a 30\%. b) a localização do restante da área exigida para as áreas verdes ficará a cargo do loteador e só será computado como área verde quando em qualquer ponto da área puder ser inscrito um círculo com raio de $10 \mathrm{~m}$, podendo ser localizado em parcelas de terreno que apresentem declividade superior a 30\%." "ao longo da águas correntes, canalizadas ou não, das dormentes e das faixas de domínio público das rodovias, ferrovias e dutos, será obrigatória a reserva de faixa non aedificandi de $15 \mathrm{~m}$ de cada lado das suas margens e dos limites da faixa de domínio. § 1 으 A faixa non aedificandi referida, quando ao longo das águas dormentes e correntes, deverá ser utilizada para sistema viário ou áreas verdes, dispensa a obrigatoriedade da inscrição do círculo de raio de $10 \mathrm{~m}$, constante na alínea ' $b$ ', do item IV, deste artigo. § 3으 Quando o espaço destinado às vias de circulação não atingir o índice estabelecido na alínea 'a', do item III, desse artigo a área necessária para completar esse índice será adicionada às áreas verdes".

(8) DOLLFUSS, Olivier. O espaço geográfico. Rio de Janeiro: DIFEL/Difusão Editorial S.A., 1978. "De modo que, no espaço dos países subdesenvolvidos, laços de dependência entrecruzam-se em diversas escalas; verifica-se, segundo o linguajar dos economistas, uma inarticulação entre as diversas partes do espaço geográfico, as quais evolvem e vivem obedecendo a ritmos desiguais. Há um enrijecimento dos interesses individuais. O comerciante, quer local quer de fora do grupo, torna-se mais poderoso e aufere uma renda cujo peso é ainda mais difícil de ser suportado pelo fato de a economia e a circulação se basearem em redes modernas, mesmo que deficientes e rapidamente degradadas." 
espaço público. Pela situação observada pode-se concluir que a manutenção dos espaços livres públicos da cidade tem sido mais eficiente quanto mais restrito à elite é o acesso a esses espaços.

Essa segregação inexiste em termos geográficos, mas é real em termos espaciais. A área apresenta como um mosaico de favelas e condomínios, ambos fechados, para quem não "pertença ao local". A sociedade fragmentada não reconhece o outro, as classes sociais extremas (o miserável e o rico) que moram no Morumbi aparentemente "não podem conviver"; assim, não existe a necessidade ou a possibilidade do espaço público. $\bigcirc$ esvaziamento do espaço público é conseqüência da falência da vida em sociedade. $\bigcirc$ encontro dos "iguais" só se dá atrás das portarias dos prédios, dos clubes, das escolas e até dos parques "públicos". A região onde moram "os mais ricos do país", apresentando mansões com milhares de metros quadrados", edifícios de apartamentos com até $865 \mathrm{~m}^{2}$ de área privativa, avaliados em US\$2.500.000,00 ${ }^{10}$, localizados a 500 metros de uma favela com 25.000 habitantes, inventa o parque "público, mas nem tanto". O Parque Burle Marx é fruto da negociação entre a prefeitura e o grupo Moinho Santista que está implantando na região os empreendimentos articulados pelo plano desenvolvido para o Panamby. Os investidores pretendiam aproveitar os jardins, originalmente projetados por Burle Marx para uma mansão nunca concluída, como um reservado clube de golfe, mas a prefeitura exigiu que a área fosse doada e aberta ao público, e a implantação do parque bancada e gerida pelos próprios investidores. Hoje, tem-se um parque "público" inacessível aos excluídos, vigiado e mantido como um condomínio privado, com uma freqüência quase tão elitizada quanto a dos clubes da região.

Pode-se observar essa mesma questão na Barra da Tijuca, no Rio de Janeiro, e em Alphaville, em Barueri.

A Barra é o bairro mais segregado do Rio de Janeiro: lá praticamente não existem favelas; ainda assim os espaços livres são em sua maioria privados, apenas a praia é realmente pública. $\bigcirc$ Parque Arruda Câmara se situa no coração da Barra, afastado de qualquer representante de classes sociais menos favorecidas - ainda que seja acessível pelas linhas de ônibus que transitam pela avenida das Américas. Some-se a isso o fato que a população, certamente,

(9) Inclusive a maior do país, com $11.000 \mathrm{~m}^{2}$, distribuídos em cinco andares e unidos por nove elevadores. Pertencente ao banqueiro Joseph Safra.

(10) A média da área é composta por apartamentos de $265 \mathrm{~m}^{2}$ com 2,6 vagas na garagem. 
prefere a praia ao parque. Apenas os moradores da Barra se utilizam do parque, o que garante a segregação e a boa manutenção desse espaço.

O governo do estado instalou, nos anos 80, um parque junto ao rio Tietê, o Núcleo Tamboré, parte de um conjunto de parques projetados para o Vale do Tietê. Esse parque faz divisa com alguns dos residenciais de Alphaville, mas é freqüentado somente pela população dos municípios de Jandira, Carapicuíba e Barveri, que se utiliza do parque e de suas adjacências nos fins de semana, transformando cada braço do rio em praia ou piscina pública.

parque é utilizado pela população pobre de Jandira, Carapicuíba e Barueri, mesmo sem dispor de linhas de ônibus ou calçadas que lhe dêem acesso. Já a população de Alphaville não utiliza o parque, o condomínio não abre nenhuma via de acesso a ele. Os espaços livres internos ao condomínio são cuidados pelo próprio condomínio, pelo menos aqueles espaços entendidos como estratégicos para a valorização do conjunto, os canteiros dos acessos e avenidas principais. $\bigcirc$ Parque Tamboré, praticamente a única alternativa de lazer público da região, é mantido pelo Estado, sendo que sua manutenção é pouco sistemática e, em vários aspectos, deixa a desejar.

É impressionante notar que o espaço público mais significativo, de maior porte de toda a região, o Parque Tamboré, ao contrário do Parque Burle Marx para o Panamby, não é apresentado como um elemento de venda ou como um dos atrativos comerciais para Alphaville, pois "não pertence" aos seus moradores, "não participa" de suas vidas. Para os moradores de Alphaville existem os clubes, os equipamentos condominiais, as praças e as ruas tranqüilas dos condomínios e os shoppings, mas o parque, ainda que vizinho, parece não existir.

A alameda Rio Negro, que é o principal acesso de Alphaville, tem seu canteiro central lindamente tratado, cuidadosamente ajardinado e mantido. Esse cuidado vai diminuindo conforme se penetra nos empreendimentos. As demais avenidas apresentam canteiros mais simples e despojados e, em alguns trechos, taludes gramados ou tomados pelo mato. As avenidas são tratadas como rodovias, ladeadas por taludes e jardins, com longos trechos sem calçadas.

Alphaville é a cidade concebida pelo empreendedor, uma conseqüência do "sonho" da classe média. As "estradas" de circulação 

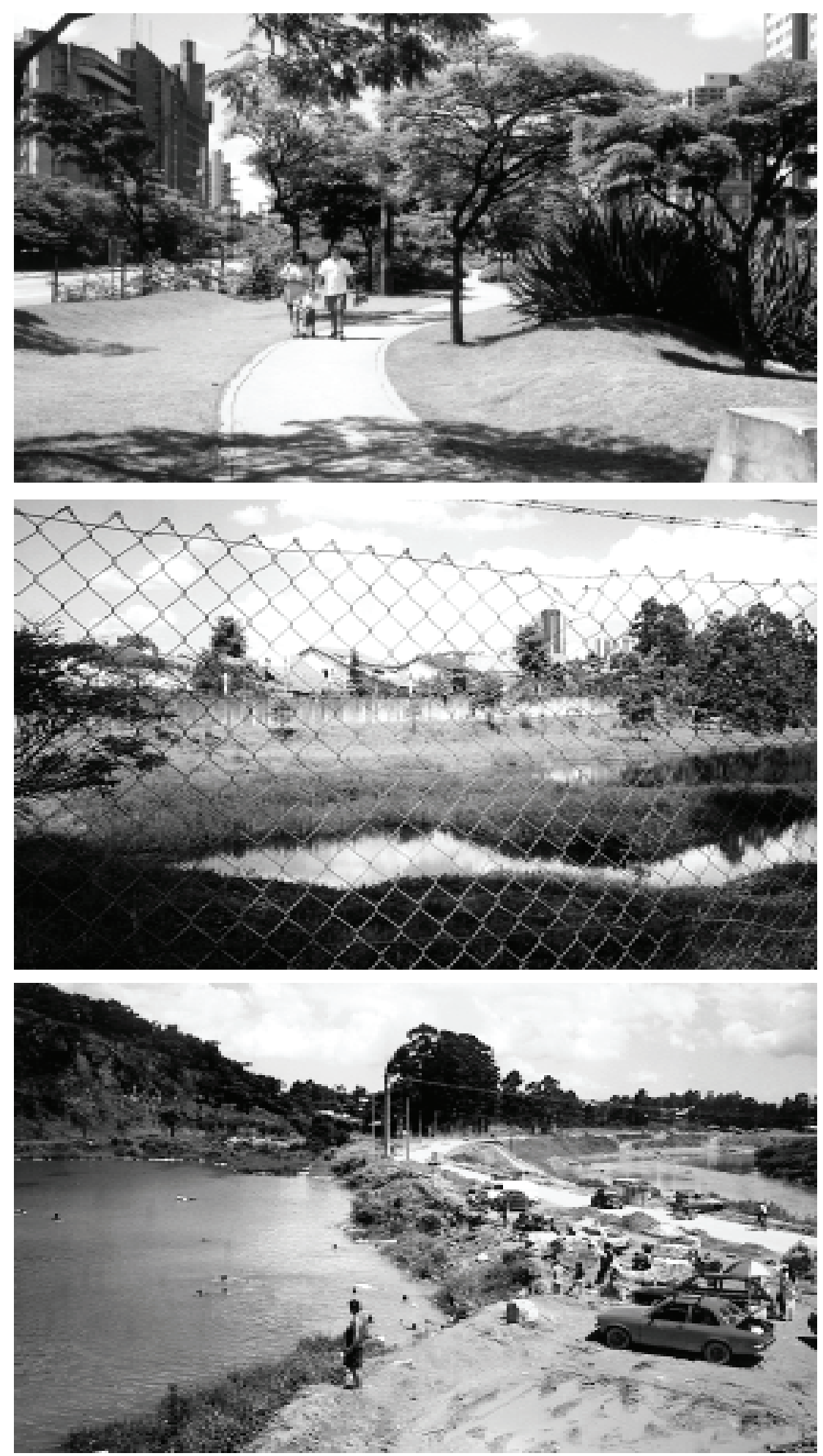

Figuras 1, 2 e 3: A alameda Rio Negro, um espaço público, mas de acesso e utilização controlados, recebe um tratamento primoroso e sofisticado que valoriza o acesso aos condomínios e empreendimentos de Alphaville. Enquanto as lagoas às margens do rio Tietê, públicas e acessíveis às populações de Barveri, são cercadas (Figura 2), ou "abandonadas" pelos investidores ou pelo estado e intensamente utilizadas pela população como perigosa alternativa de lazer nos fins de semana (Figura 3). Crédito: Autor 
entre os residenciais, ladeadas por muros e taludes, são normalmente desertas. Nenhum pedestre e pouquíssimos ciclistas se aventuram a percorrê-las. Desinteressantes e íngremes, essas avenidas seguem por centenas de metros de portaria em portaria sem qualquer outro elemento além dos muros e taludes.

As vias desertas de Alphaville, do Morumbi e da Barra da Tijuca revelam diferentes manifestações das mesmas estratégias de esvaziamento do significado dos espaços livres públicos, engendradas pelas elites em seus bairros. As ruas centrais de São Paulo ou do Rio de Janeiro, as ruas de bairros como Pinheiros ou Penha apresentam a mesma vitalidade e utilização que marcaram estas áreas ao longo do século 20. Para garantir que as ruas dos bairros destinados às elites permaneçam desertas ou de uso exclusivo de seus moradores, os empreendedores e seus arquitetos têm de recorrer a artifícios cada vez mais eficientes e vulgares.

Vale ressaltar que se essas estratégias funcionam nestes, e em outros bairros elitizados, os espaços livres urbanos, porém, continuam apresentando incrível vitalidade em outros bairros paulistanos e municípios brasileiros. Não estamos dizendo que os espaços livres públicos urbanos estão em decadência, muito menos mortos. Estamos denunciando que nos bairros de elite eles têm sido premeditadamente esvaziados como parte de estratégias segregacionistas engendradas pelo mercado imobiliário.

Acrescenta-se ainda que, pelo fato de algumas classes sociais terem construído modos de socialização que prescindem dos espaços livres públicos urbanos, parte da mídia (especializada ou não) tem veiculado que a idéia e a utilidade do espaço livre público está em xeque. Os jornais e revistas mostram como os espaços estão "invadidos" por camelôs, mendigos e miseráveis e que, portanto, a "população" não os usa mais! Este encaminhamento da discussão é equivocado e perigoso - equivocado por inverter a relação de causa e efeito, pois os espaços espelham as condições da própria sociedade. A melhoria das condições dos espaços urbanos depende de melhorias das condições de distribuição de renda, de acesso à educação e à cidadania pela população e não da exclusão de uma ou outra classe.

\section{Questões Ambientais e Paisagísticas}

O sítio sobre o qual se implanta a região do Morumbi é especial e interessante. Sua configuração complexa, recortada por córregos, 
dramatizada pelas encostas íngremes, com grotões vegetados e vários mirantes naturais, poderia ser aproveitada e incorporada à paisagem urbana, gerando contextos ricos e diversificados.

Contudo se percebe, ao percorrer a área, que os potenciais paisagísticos e ambientais foram desperdiçados e destruídos pela cupidez, falta de visão ou mediocridade dos vários agentes produtores da paisagem.

Quando se penetra no Parque Alfredo Volpi (antigo Bosque do Morumbi) e depara-se com o pequeno lago e a beleza dos bosques que cobrem as encostas, chega-se a acreditar que se está diante de uma situação única na paisagem da região. Engano, pois existiriam outros tantos grotões com características semelhantes que poderiam abrigar vários parques como esse. A devastação da vegetação de porte da região e os grandes movimentos de terra destruíram várias dessas situações, desperdiçando oportunidades paisagísticas.

Três aspectos concorrem para inviabilizar um aproveitamento mais racional e interessante das qualidades naturais ou originais da paisagem:

a) a legislação e a ocupação pensada e implementada lote a lote;

b) o desinteresse do mercado e dos moradores pela existência dos espaços livres públicos;

c) a ausência ou omissão do Estado.

Quanto ao primeiro aspecto, deve-se lembrar que a legislação vigente estabelece normas para a produção da cidade em dois momentos: durante o traçado do loteamento urbano e, depois de loteado, normatizando a edificação dentro dos lotes.

Como já foi dito, a lei municipal que regulamenta o parcelamento do solo é a de n. 9.413, de 1981. Essa lei estabelece as situações nas quais não se pode lotear ${ }^{11}$, mas não informa o que fazer com as áreas que restariam sem lotear. Em síntese, a questão é a seguinte: admitindo-se que existem situações morfológicas do sítio que não

(11) A Lei Municipal n. 9.413, de 30 de dezembro de 1981, dispõe sobre o parcelamento do solo no Município de São Paulo, estabelecendo que "não será permitido o parcelamento do solo: a) em terrenos alagadiços e sujeitos a inundações, antes de tomadas as providências para assegurar a drenagem e escoamento das águas; b) em terrenos que tenham sido aterrados com material nocivo à saúde pública, sem que sejam previamente saneados; c) em terrenos com declividade igual ou superior a 30\%, salvo se atendidas exigências específicas da legislação municipal; d) em terrenos onde as condições geológicas não aconselhem a edificação; e) em áreas de preservação ecológica ou naqueles onde a polvição impeça condições sanitárias suportáveis até sua correção". 
devem ser alvo de loteamento, cabe perguntar: que outra destinação terão essas situações?

A legislação simplesmente estabelece onde não se pode edificar, não obriga o Estado ou o proprietário a cuidar ou dar alguma destinação a essas áreas. A lei reserva áreas junto aos córregos, mas não garante a qualidade das águas ou a proteção das suas margens.

Assim, percebe-se, em toda área, que quando a iniciativa privada encontra qualquer elemento perturbador do aproveitamento pleno da área de que dispõe, ela tenta removê-lo. As áreas de declividade maior são desmontadas e terraplenadas; os córregos menores, canalizados e aterrados, e as matas, derrubadas na calada da noite ${ }^{12}$.

As áreas que por força de lei permanecem livres e públicas acabam virando "terra de ninguém", espaços de despejo de entulho e lixo ou ocupados por favelas. Esse abandono dos espaços livres acarreta enormes prejuízos às condições ambientais. Basta perceber que as áreas livres transformadas em área de despejo de lixo e entulho são justamente as que ficam junto aos córregos e nas áreas de maior declividade. Daí pode-se concluir que as leis concebidas para a proteção dos elementos e sistemas naturais acabam por engendrar sua destruição, pela incompetência e omissão do Estado ao fazê-las cumprir efetiva e adequadamente.

(12) A Lei Municipal n. 10.365, de 22 de setembro de 1987 que disciplina o corte e a poda de vegetação de porte arbóreo existente no Município de São Paulo, e dá outras providências, tenta proteger a vegetação remanescente dentro do município estabelecendo que: "como bem de interesse comum a todos os munícipes a vegetação de porte arbóreo existente ou que venha a existir no território do Município, tanto de domínio público como privado... Considerase de preservação permanente a vegetação de porte arbóreo que, por sua localização, extensão ou composição florística, constitua elemento de proteção ao solo, à água e a outros recursos naturais ou paisagísticos... Consideramse de preservação permanente, por força do Código Florestal, instituído pela Lei Federal n. 4.771, de 15 de setembro de 1965, com as alterações e acréscimos da Lei Federal n. 7.511, de 7 de julho de 1986, as florestas e demais formas de vegetação situadas: a) ao longo dos rios ou de outro qualquer curso d'água, em faixa marginal, b) ao redor das lagoas, dos lagos ou reservatórios d'água, naturais ou artificiais; c) nas nascentes, mesmo nos chamados olhos d'água, seja qual for sua situação topográfica; d) no topo dos morros, montes, montanhas e serras; e) nas encostas ou partes destas, com declividade superior a $45^{\circ}$, equivalente a $100 \%$ na linha de maior declive... Art. 5․ A supressão, total ou parcial, de florestas e demais formas de vegetação consideradas de preservação permanente, de acordo com o artigo 4ํ desta lei, só será admitida, com prévia autorização do Executivo Municipal, quando for necessária à implantação de obras, planos, atividades ou projetos, mediante parecer favorável de comissão especialmente designada. § 3을 qualquer caso de supressão irregular da vegetação de porte arbóreo considerada de preservação permanente, a área originalmente revestida pelas formações correlatas permanecerá em regime de preservação permanente, de forma a possibilitar sua recuperação mediante planos de reflorestamento, ou de regeneração natural, de acordo com orientação do Departamento de Parques e Áreas Verdes - DEPAVE, da Secretaria de Serviços e Obras - SSO. Art. 6․ Os projetos de loteamento e desmembramento de terras, em áreas revestidas, total ou parcialmente, por vegetação de porte arbóreo, deverão ser submetidos à apreciação do Departamento de Parques e Áreas Verdes - DEPAVE, da Secretaria de Serviços e Obras - SSO, antes da aprovação final pelo Departamento de Parcelamento do Solo e Intervenções Urbanas - PARSOLO - INTERURB, da Secretaria de Habitação e Desenvolvimento Urbano - SEHAB." 
Para comprovar essa afirmação, basta lembrar que parte significativa das favelas do município localiza-se justamente nas situações que a lei se propõe a proteger ${ }^{13}$.

Em 1989, durante um período de chuvas, uma encosta que vinha sendo aterrada com material retirado de várias outras obras da região acabou deslizando, no fundo do vale, junto a um córrego onde havia uma favela chamada Nova República. Vários barracos foram soterrados, 15 pessoas morreram, sendo que 12 delas eram crianças $^{14}$. Acidentes desta natureza não são raros, pois, na região do Morumbi, como em toda a metrópole paulistana, essa convivência entre aterros, córregos e favelas é a conseqüência freqüente e perversa da legislação e das práticas vigentes.

Estado proíbe o loteamento das situações mais delicadas e especiais do sítio, mas não lhes dá destinação alguma ou garante qualquer outra qualidade além de simplesmente não serem loteadas. A iniciativa privada também não demonstra qualquer preocupação com a questão e acaba por destruir ou simplesmente abandonar essas áreas.

É importante frisar que a cidade de São Paulo jamais teve um plano para suas áreas livres. $\bigcirc$ máximo que existiu foram capítulos genéricos dedicados ao meio ambiente ou às áreas verdes dentro dos inócuos planos diretores. $\bigcirc$ poder público - o único responsável pela implantação, gestão e manutenção de espaços livres públicos como ruas, praças e parques - já realizou vários planos para São Paulo (viários, de abastecimento, de saneamento ou de canalização e drenagem de córregos). Contudo, não foi realizado um único plano ou projeto que tratasse dos espaços livres públicos. Nesse assunto, como em tantos outros, houve uma histórica e imperdoável omissão do Estado.

Por toda a região assiste-se ao desrespeito pelos elementos naturais: os córregos estão sendo canalizados e transformados em esgo-

(13) "49,3\% das favelas de São Paulo têm alguma parte localizada em beira de córrego, 32,2\% estão sujeitas a enchentes, 29,3\% localizam-se em terrenos com declividade acentuada, 24,2\% estão em terrenos que apresentam erosão acentuada e 0,9\% estão em terrenos de depósitos de lixo ou aterro sanitário. Do total, $65 \%$ estão situadas em área pública e $9 \%$ em terrenos de propriedade mista, ou seja, pública e privada. Esses dados são de 1987, quando o número de favelas era de aproximadamente 1.600 núcleos, onde moravam cerca de 8\% da população. Em 1993 essa proporção sobe para 19,8\%". Fonte: São Paulo, Município - SEHAB. Censo de Favelas do Município de São Paulo, 1987. In: MARICATO, Ermínia., 1996, op. cit., p. 58 ou em VÉRAS, Maura, Pardini B. e Suzana Pasternak Taschner. Evolução e mudanças das favelas paulistanas. Espaço \& Debates, n. 31, Revista de Estudos Regionais, ano X, 1990, p. 57.

(14) Essa calamidade poderia ter sido evitada, pois no Plano Diretor do Município de São Paulo, desenvolvido em 1985 (na gestão do prefeito Mário Covas), a área era apontada como sujeita à erosão e merecedora de medidas especiais, mencionando a necessidade de um Plano de Ocupação de Fundos de Vale, não-detalhado. Novamente, fica provada a descontinuidade administrativa e a inutilidade dos planos diretores. 
tos, os morros desmontados e cortados e as matas gradativamente derrubadas. Os elementos e sistemas naturais da região do Morumbi estão seriamente comprometidos.

\section{Questões Sociais}

Exemplos alemães, ingleses e espanhóis mostram a preocupação dos urbanistas, arquitetos e críticos dessas experiências acerca da dimensão cultural e cívica das obras urbanas.

Quando, entretanto, questionam-se modelos de urbanização, não se pode esquecer o fundamental para a análise da validade de qualquer obra urbanística: a dimensão social.

Existem peculiaridades da estrutura social que acabam por singularizar qualquer fenômeno observado neste país. Pensando-se na questão da saúde pública, da educação ou mesmo do desenvolvimento industrial e tecnológico brasileiro, as condicionantes da nossa sociedade engendram limites e peculiaridades nacionais para a situação dessas questões.

O processo de metropolização brasileiro insere-se em um processo planetário de migração de população para as metrópoles, contudo poucos países no mundo abrigam uma rede urbana com a dimensão e a extensão da brasileira. As metrópoles brasileiras apresentam um quadro de pobreza, violência, congestionamento, desequilíbrio ambiental e social que, se não são únicos no mundo, certamente apresentam peculiaridades e diferenças mesmo quando comparadas com outras metrópoles de países periféricos e subdesenvolvidos como o Brasil.

Por décadas acreditou-se que a realidade de nossas metrópoles não vinha à tona, não aparecia na mídia, por um controle dos meios de comunicação imposto pelo Estado. Hoje, em condições de razoável liberdade e democracia, percebe-se que a mídia está a tal ponto comprometida com a manutenção da ideologia dominante que a cidade real permanece ausente da mídia, das ações do Estado e muito longe de ser conhecida ou reconhecida pela população dita "esclarecida" ou "formadora de opinião".

Fato é que, quando se observam bairros como Higienópolis, em 24 São Paulo, ou Copacabana, no Rio de Janeiro, causa espanto a urbanidade que encerram. São segmentos urbanos que reúnem modos de vida em comunidade com dimensões culturais e urbanas de países desenvolvidos. Nesses bairros existia, e pode-se dizer que 
ainda existe, uma "cultura pública", como definida por Russel Jacoby $^{15}$ : um modo de vida que se utiliza dos espaços públicos, estabelecendo uma convivência rica, complexa e possível entre pessoas de diferentes grupos sociais.

Higienópolis começou a verticalizar-se na década de 40, quando Copacabana era o paradigma válido para todo o Brasil. Essa geração de edifícios se relacionava com as ruas de modo direto. Os edifícios ora apresentavam pequenos recuos de frente, ora implantavam-se nos alinhamentos, com suas janelas e portas abrindo-se diretamente para as calçadas. Morar nesses edifícios significava morar nesses bairros, andar por suas ruas, freqüentar seus espaços públicos e conhecer seus moradores. Essa dimensão de vida urbana, essa "cultura pública", solidária e cotidiana dava-se pelo território. Existiam razoáveis diferenças sociais entre os moradores do mesmo bairro, existiam casas e famílias mais ricas e menos ricas, existiam moradores tradicionais e moradores recentes.

Conforme essas diferenças vão se radicalizando, no conjunto da sociedade, o vínculo com o local desaparece. $\bigcirc$ vínculo social já não é capaz de abarcar classes tão diferentes simplesmente pela relação de vizinhança, passa-se, então, a buscar os "iguais" em territórios que garantam essa identidade.

Alphaville, Barra da Tijuca e Panamby são bairros sem pobres, nos quais a segregação social está garantida pelo controle do acesso à terra (pela valorização e propriedade) e pelo controle dos meios de locomoção, circulação e transporte. Grandes distâncias, pequenas e monótonas calçadas, transporte baseado no automóvel, segurança privada, muros e processos intimidatórios logram a exclusão dos "diferentes" e indesejados.

Ainda assim, ou talvez por conseqüência desses mesmos procedimentos, os moradores dessas áreas estão ausentes dos espaços livres públicos ou semipúblicos. A vida desses bairros se dá nos clubes, shoppings, centros empresariais e escolas. Espaços nos quais a segregação se alia a outros fatores de interesse grupal, permitindo aglomerações sem risco de "promiscuidade social". Essas classes pagam o preço da segregação, altos custos condominiais pela segurança e manutenção das áreas privadas, altos custos das mercadorias dos shoppings que desencorajem (ou impeçam) os representantes das classes menos favorecidas de freqüentar espaços, escolas e clubes mais caros e privados. 


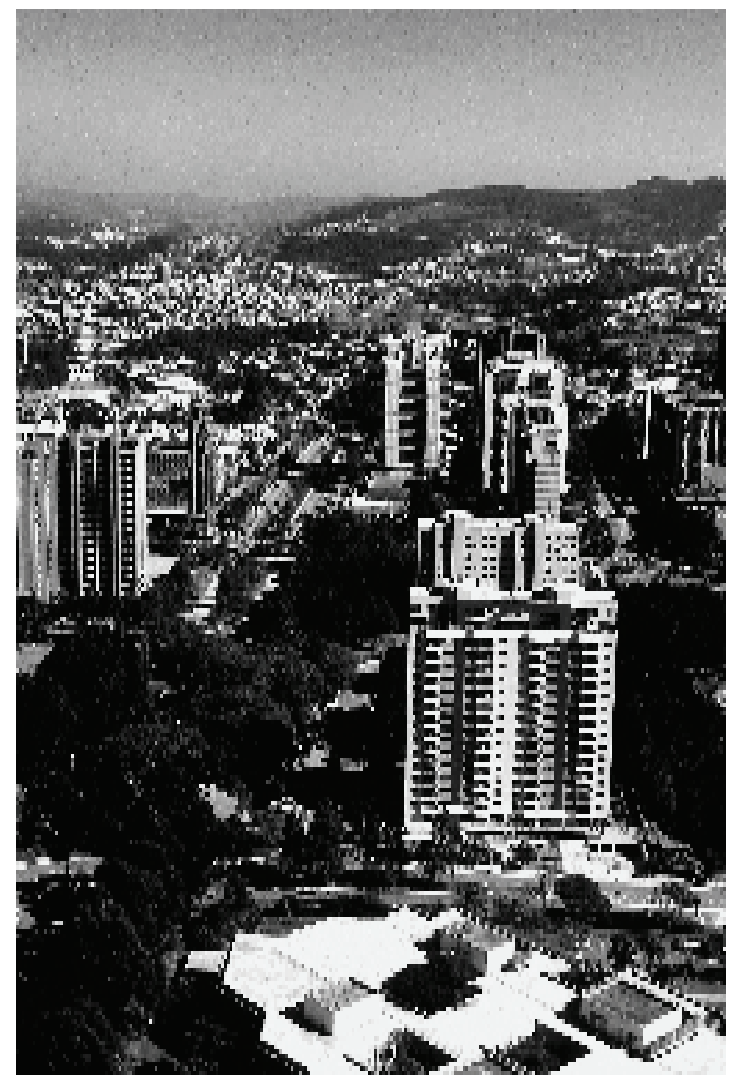

Figura 4 - As lógicas comerciais que regem empreendimentos como Alphaville impõem enormes movimentos de terra, com graves prejuízos ambientais, e a concepção de sistemas de espaços livres estéreis, segregados e sem qualquer utilidade para a preservação ou recuperação dos sistemas naturais devastados. Têm-se espaços cênicos sem qualquer utilidade social ou ambiental Crédito: Autor

As áreas de interesse das elites podem situar-se em qualquer lugar da cidade, podem distar quilômetros das residências, desde que sejam de fácil acesso e ofereçam estacionamentos suficientes.

Se na Barra da Tijuca e em Alphaville os espaços livres públicos têm pouco significado, não são fundamentais; na região do Morumbi eles são "indesejáveis". A relação que os moradores das casas e das torres do Morumbi têm com as ruas do bairro é simplesmente pelas janelas de seus carros.

Como pode um planejador fazer qualquer proposta para esse contexto social? Admitindo-se que a sociedade da região é composta desses dois extremos sociais, a questão parece realmente insolúvel.

Qualquer plano que atenda aos interesses dos moradores dos prédios pressupõe a remoção dos favelados. Qualquer proposta de regularização fundiária da Favela do Paraisópolis ${ }^{16}$ parece preten-

(16) Existe uma polêmica histórica acerca da remoção dessa favela. Em 1972, a área da favela foi classificada como zona 8.029, praticamente congelando a área pelas exigências de recuos superiores aos da Z1, recuos frontais, de fundos e laterais, de ambos os lados de 10 metros, taxa de ocupação de 0,0125\% e coeficiente de aproveitamento de $10 \%$. Em 1978, foi aprovada nova Lei n. 8.769, de 31/08/78, ampliando a área de Z8 e propondo uma operação urbana de desapropriação da área abandonada pela gestão seguinte. Desse modo, a área continua apresentando um contraditório quadro institucional e permanece como uma favela com cerca de 1.550 .000 m², no "coração" do Morumbi. 
der a posterior compra da área e a remoção dos quase 25.000 moradores. Hoje, contam-se na região inúmeras favelas e uma população total estimada em mais de 50.000 favelados. Não é provável que os investidores consigam, mesmo em décadas, resolver todas as questões fundiárias e institucionais, além de reunir o capital necessário para bancar a remoção de toda a população miserável e pobre da região, que nas últimas décadas só faz crescer.

As mansões da região entraram em crise no fim dos anos 60 e na década seguinte, período em que o número de assaltos às residências da área passa a alarmar os moradores e a ganhar as páginas dos jornais e revistas. Parece que o modelo estabelecido de ocupação de elite - baseado em condomínios fechados, horizontais e verticais, vigiados como fortalezas urbanas - vem viabilizando, a um altíssimo custo financeiro e social, essa vizinhança sem convivência de classes sociais extremas. Favelas e prédios têm prosperado lado a lado.

A paisagem do Morumbi, de Alphaville ou da Barra da Tijuca é o reflexo da "estética da violência", como é definida por Teresa Caldeira $^{17}$, o confronto entre riqueza e miséria mediado por muros, grades e guaritas.

Sem que o quadro social do país sofra alterações significativas não se pode esperar soluções conciliatórias para a região do Morumbi. Com esse quadro social em que miséria e riqueza extremas convivem agredindo-se reciprocamente, a ocupação da área continuará a espelhar a violência e a estupidez da sociedade brasileira.

\section{O Papel do Estado e do Planejamento}

O papel do Estado na sociedade contemporânea brasileira é retratato por Milton Santos, quando explica o significado de "metrópole corporativa" $^{18}$. Ele mostra que o poder público alardeia uma crise fiscal, demonstrando matematicamente sua incapacidade de suprir as carências metropolitanas, enquanto prioriza seus investimentos em infra-estruturas que atendem aos oligopólios hegemônicos. $\bigcirc$ processo é mais perverso quando se verifica que o principal aglutinador do capital destinado a essas obras foi justamente o Banco Nacional de Habitação (BNH), que subtraía compulsoriamente

(17) CALDEIRA, Teresa P. R. City of walls: Crime, segregation, and citizenship in São Paulo. Dissertation for degree of doctor of philosophy in antropology in the Graduate Division of the University of California at Berkeley, 1992.

(18) SANTOS, Milton. Metrópole corporativa fragmentada: O caso de São Paulo. São Paulo: Nobel, 1990. p. 95. 
parte dos salários dos trabalhadores para investimentos que facilitavam o lucro das indústrias, "estimulando a instalação de novas indústrias".

Essa aliança entre Estado e capital privado engendra um processo de urbanização baseado em servir diferentemente às diversas áreas da cidade, permitindo lucros extraordinários aos incorporadores ${ }^{19}$.

Contudo, por mais poderosos que sejam os oligopólios, por maior que seja o controle que os grupos dominantes tenham sobre o poder público, a região do Morumbi parece manter-se em desacordo com seus interesses.

Nos últimos anos assistiu-se à consolidação do projeto mais amplo de deslocamento de parte das atividades centrais, de interesse dos grupos hegemônicos, para o vale do rio Pinheiros. O prolongamento da avenida Faria Lima, a abertura de uma nova ligação a leste pela avenida das Águas Espraiadas e a construção de novos pontos de travessia do rio, com as novas pontes e túneis, consolidaram a vocação da margem oeste como a moradia das elites. As administrações municipais se empenharam em dotar essa região da infraestrutura necessária para as novas atividades, veiculando o discurso ideológico da "montagem de uma metrópole globalizada". Grupos de investidores nacionais e internacionais apressaram-se em garantir áreas para seus empreendimentos na região.

Desse modo, tem-se na margem oeste do rio Pinheiros um conflito aberto entre as aspirações das elites em segregar-se em um contexto plenamente controlado e privativo, retrato de sua modernidade, e de sua capacidade real de expulsar, utilizando o poder do capital, populações marginais ao mercado capitalista estabelecido e legal.

Como Milton Santos teoriza - "a força dos fracos é seu tempo lento" ${ }^{20}$ - a mobilidade das classes não-hegemônicas é menor por suas limitações intrínsecas e porque é necessariamente negociada. Nesse caso específico, os moradores das favelas da região já perceberam seu alto poder de barganha e não estão dispostos a aceitar sua remoção.

(19) RIBEIRO, Luiz César de Queiroz. Dos cortiços aos condomínios fechados: As formas de produção da moradia na cidade do Rio de Janeiro. Rio de Janeiro: Civilização Brasileira: IPPUR,UFRJ, 1997. "A condição fundamental para a consolidação da incorporação imobiliária já estava dada: a diferenciação social, expressa no espaço da cidade, na dupla dimensão simbólica e material, como base para a geração de sobrelucros de localização.", p. 299.

(20) SANTOS, Milton. Técnica, espaço, tempo. Globalização e meio técnico-científico informacional. São Paulo: Hucitec, 1994. p. 81. 
poder público participa desse conflito de modo contraditório. A mesma gestão que articulou a compra dos barracos e a remoção dos moradores, para a passagem da avenida Águas Espraiadas, na margem leste, construiu edifícios do programa Cingapura na outra margem, consolidando a permanência dos seus moradores.

Existe uma saída possível pela negociação das condições de permanência, o que parece ser a tendência do confronto. Os grupos dominantes terão que se reconhecer não-hegemônicos, terão que admitir sua incapacidade de impor seu projeto sobre os demais. Desse modo, as partes estabelecerão as condições de convivência entre elas. Esse acordo terá que se dar para que exista a possibilidade de disciplinar a urbanização da área, estabelecendo um sistema de áreas livres com reais significados urbanos.

Analisando-se as tendências contemporâneas do planejamento urbano, percebe-se a ênfase dada ao espaço livre público como o principal elemento estruturador das cidades, pois é nele que se constrói a cidade e a cidadania. Os principais projetos urbanísticos desenvolvidos atualmente na Europa partem da importância e da qualidade dos espaços livres públicos, e assumem como responsabilidades fundamentais e intransferíveis do Estado gerá-los e geri-los.

A base da solução negociada possível para a região do Morumbi está no reconhecimento do direito à cidadania de todos os seus habitantes, na reconstrução da possibilidade de convivência entre eles. Um desafio para o Estado e para todos os que moram na área. Só então se pode imaginar soluções verdadeiras para a qualificação da paisagem urbana.

Soluções como a Barra da Tijuca, Alphaville ou Panamby, por só existirem como paisagem de exclusão, são falsas soluções. São paisagens que sobrevivem enquanto puderem manter-se segregadas da cidade real, criando a falsa noção de coerência ideológica pela omissão da verdade social. Essas áreas abandonam os espaços livres públicos, simplesmente porque sua pobre estrutura social, segregada e artificial, não inclui a vitalidade necessária para a apropriação verdadeiramente democrática da paisagem urbana.

Remover os 50.000 moradores das favelas da região do Morumbi é viabilizar a falsa solução, negando a possibilidade de coexistência das várias classes sociais paulistanas e o próprio direito à cidadania dos favelados. Ao se expulsar essa população, estão-se criando condições artificiais para a existência dos espaços livres "públicos". 
Estado tem, pois, duas alternativas: pode ser o promotor desse acordo, da permanência negociada ou, pelo contrário, mantendo seu papel histórico, pode perpetuar-se como instrumento de dominação, viabilizando a expulsão. Contudo, apenas quando uma dessas duas soluções se completar será possível estabelecer um sistema de áreas livres capaz de proteger e incorporar os elementos e sistemas naturais da paisagem da região. Somente quando o conflito estiver superado é que se poderá ter uma paisagem urbana com um mínimo de qualidade paisagística e ambiental.

Não se pretende invalidar qualquer trabalho de projeto urbano, pois se acredita na necessidade do planejamento para que se tenha um mínimo de qualidade, eficiência e harmonia no espaço construído. Entretanto, após esses anos de investigação, durante os quais, mais do que respostas, buscava-se a questão fundamental a ser discutida, conclui-se que o papel dos urbanistas atravessa um dilema conseqüente da crise que se impõe às elites dominantes nacionais.

Fundamentalmente percebe-se que as elites dominantes, por não serem mais hegemônicas, são incapazes de incorporar em seus planos a cidade real, a que é habitada por cerca de 70\% da população municipal. $\bigcirc$ Estado, por ser "incapaz" de atender às demandas das demais classes, acaba criando mecanismos ideológicos e institucionais que justifiquem esse desatendimento.

Um dos expedientes ideológicos empregados é "a generalização do particular". Esse expediente é o artifício de apresentar o interesse de determinado grupo ou classe social como interesse coletivo. Villa$\mathrm{ça}^{21}$ mostra, por meio de recortes jornalísticos, como, nos principais jornais e revistas da cidade, o que é notícia, o que ganha espaço na mídia, é a cidade que interessa às elites. Tem maior repercussão na mídia o fechamento de alguns escritórios ou lojas na alameda Gabriel Monteiro da Silva do que a remoção de várias favelas na área dos mananciais.

As periferias, os bairros operários ou industriais, mesmo que representem a maior parte da área da cidade ou que abriguem a maioria da população, não são vistos nos noticiários ou nos mapas na mesma proporção que os bairros das elites. Desse modo, o Estado constrói sua autorização para administrar "a cidade que interessa ",

(21) VILLAÇA, José Magalhães, 1989, op. cit. 
para localizar seus principais investimentos e obras "nesta cidade". Contudo, como ficou demonstrado neste trabalho, mesmo na "cidade que interessa", a elite e o Estado falham ao fazer valer seus interesses, por não lograrem uma paisagem urbana com qualidades mínimas.

Em contextos previamente controlados e artificialmente mantidos podem-se criar segmentos urbanos que satisfaçam os interesses e anseios do mercado formal. Essas áreas funcionam baseadas na segregação, exclusão e funcionamento esquemático e controlado das atividades urbanas. Tornam-se, pois, caricaturas urbanas empobrecidas de qualquer significado cívico ou social. Os espaços livres, nesses contextos, carecem de vitalidade urbana por não serem públicos e muito menos urbanos ${ }^{22}$.

grande projeto construído nas últimas décadas pela elite paulistana, que estabelece a região do Morumbi como seu bairro de moradia, esbarra na existência de dezenas de favelas em seu interior e muitas outras em sua vizinhança imediata.

Só existirão as condições necessárias para a reconstrução da noção de espaço livre em bairros de elite quando a sociedade estiver madura e preparada para aceitar que diferenças sociais não devem ser necessariamente resolvidas pela exclusão e segregação.

Isto, hipoteticamente, pode acontecer na região do Morumbi.

Caso isso ocorra, talvez já seja tarde demais para que se possa tirar algum proveito do rico suporte natural sobre o qual essa área se assentou. Estão se desperdiçando, dia a dia, recursos públicos e privados, pois se constrói uma paisagem sem nenhuma qualidade ambiental, funcional ou estética, simplesmente porque hoje não existem as condições necessárias, nem os agentes públicos ou privados, interessados em garantir qualquer dessas qualidades para a região.

Restituir ao conjunto dos espaços públicos a unidade é restituir-lhe a cidade e a cidadania. Segundo Phillippe Panerai ${ }^{23}$, "é afirmar uma

(22) FRÚGOLI Jr., Heitor. São Paulo - Espaços públicos e interação social. São Paulo: Marco Zero, 1995. "O conjunto de empreendimentos dessa ordem, centrados numa série de procedimentos de mercado e agenciados sob a lógica da segregação, ameaça de várias formas o espaço público, ao abandoná-lo à mercê da deterioração, do crime e, em alguns casos, da desertificação, o que, por sua vez, reforça a adoção de medidas mais privatizantes. A cidadania, historicamente fragilizada em muitas dimensões, torna-se ainda mais problemática diante da consolidação desse quadro, pois se reformula de forma dramática a própria noção de cidade", p. 79.

(23) PANERAI, Phillippe. O retorno à cidade - O espaço público como desafio do projeto urbano. Revista Projeto, abr. de 1994. 
atenção ou um desvelo igual para todas as partes da aglomeração e recusar-se à dicotomia entre o luxo dos bairros privilegiados e o refinamento dos setores históricos, de um lado, e o abandono dos bairros deserdados. É tornar sensível a todos sua qualidade de habitante ou - no sentido original - de cidadãos".

Quando a opinião pública alemã se preocupa com os interesses escusos ou ilícitos subjacentes à enorme obra de reconstrução do centro da cidade de Berlim, está no campo do direito e da imprensa. Espera-se que a mídia acompanhe e divulgue de modo isento e crítico o processo de negociação e gerência do capital público e privado mobilizado para aquela obra. Porém, para os urbanistas, cumpre-se o dever de verificar a qualidade da cidade construída. É papel dos urbanistas observar se os espaços livres e construídos encerram as qualidades necessárias, seja qual for o volume do capital investido, para que a sociedade habite e trabalhe em uma cidade com qualidades suficientes para permanecer viva e útil por várias gerações.

Por fim, é importante reiterar que ao apontar o descaso e o desuso dos espaços livres públicos nos bairros de elite estudados, ao perceber o processo de interiorização e segregação da vida coletiva das elites brasileiras e ao salientar que a falta de cuidado com os espaços livres públicos não tem impedido o sucesso comercial dos empreendimentos realizados nos bairros em questão, acredita-se que é fundamental e urgente reelaborar o modo de gerenciamento e produção dos espaços urbanos a partir dos espaços livres públicos.

O desuso gera o lixo, a criminalidade e a privatização desses espaços, que, por sua vez, agrava o abandono, em um processo perverso que, se não é engendrado por agentes sociais específicos, podese dizer que atende aos interesses de alguns desses. Quando a sociedade brasileira alcançar novos patamares de desenvolvimento social e cultural, reconciliando-se consigo mesma, talvez se possam ver os espaços livres reassumindo sua função histórica de palco da vida social, em uma reversão desse processo.

\section{Bibliografia}

CALDEIRA, Teresa P. R. City of walls: Crime, segregation, and citizenship in São Paulo. Berkeley, 1992. Dissertation doctor of philosophy in antropology in the Graduate Division of the University of California at Berkeley.

DOLLFUSS, Olivier. O espaço geográfico. Rio de Janeiro:

DIFEL/Difusão Editorial S. A., 1978. 
FRÚGOLI Jr., Heitor. São Paulo - Espaços públicos e interação social. São Paulo: Marco Zero, 1995.

GONÇALVES, Fábio Mariz. O desenho da paisagem - A relação entre os padrões de urbanização e o suporte físico. São Paulo, 1999. Tese (Doutorado) - Faculdade de Arquitetura e Urbanismo, Universidade de São Paulo.

JACOBY, Russel. Os últimos intelectuais. São Paulo: Edusp/ Trajetória Cultural, 1990.

LEITE, Maria Angela F. Pereira. A natureza e a cidade: Rediscutindo suas relações. In: Natureza e sociedade de hoje: Uma leitura geográfica. São Paulo: Hucitec, 1993.

MARICATO, Ermínia. Metrópole na periferia do capitalismo: Legalidade, desigualdade e violência. São Paulo, Hucitec, 1996.

PANERAI, Phillippe. O retorno à cidade - $\bigcirc$ espaço público como desafio do projeto urbano. Revista Projeto, abr. 1994.

RIBEIRO, Luiz César de Queiroz. Dos cortiços aos condomínios fechados: As formas de produção da moradia na cidade do Rio de Janeiro. Rio de Janeiro: Civilização Brasileira: IPPUR,UFRJ, 1997.

SANTOS, Milton. Metrópole corporativa fragmentada: O caso de São Paulo. São Paulo: Nobel, 1990.

Técnica, espaço, tempo. Globalização e meio técnicocientífico informacional. São Paulo: Hucitec, 1994. p. 81.

VÉRAS, Maura, PARDINI, B., TASCHNER, Suzana Pasternak. Evolução e mudanças das favelas paulistanas. Espaços \& Debates, n. 31 , Revista de Estudos Regionais, ano X, 1990.

VILLAÇA, José Magalhães. Sistematização crítica da obra escrita sobre espaço urbano. São Paulo, 1989. Concurso Professor livre-docente. Faculdade de Arquitetura e Urbanismo, Universidade de São Paulo. 